\title{
SFRP1 Promoter Methylation and Renal Carcinoma Risk: A Systematic Review and Meta-Analysis
}

\author{
Shijie Mo, Zexuan Su, Baoli Heng, Weijun Chen, \\ Liping Shi, Xinghua Du and Caiyong Lai \\ Department of Urology, The First Affiliated Hospital, Jinan University, Guangzhou, China
}

\begin{abstract}
Background/Aim: Epigenetic inactivation of tumor suppressor genes is an important molecular mechanism in the formation and development of human tumors. The purpose of our study was to evaluate the correlation between the methylation level of the secreted frizzled-related protein 1 (SFRP1) gene and the risk of renal cell carcinoma (RCC).

Methods: The relevant literature was searched in detail in several electronic databases. The methodological heterogeneity was analyzed by meta-regression and subgroup analyses. The odds ratios (ORs) and their corresponding $95 \%$ confidence intervals (CIs) were calculated to summarize the dichotomous outcomes of our meta-analysis.

Results: The ten included articles contained 535 RCC samples and 475 normal controls. The results demonstrated that the methylation level of the SFRP1 promoter region was significantly correlated with an increased incidence of RCC (OR=13.72; 95\% CI: 6.01-31.28; P=0.000). Furthermore, the eligible studies that had sufficient clinical data about the RCC cases were included in the analysis, and the results indicated that the frequency of SFRP1 promoter methylation was associated with a higher histological grade ( $\mathrm{P}=0.000)$, tumor stage $(\mathrm{P}=0.033)$, tumor size ( $\geqq 5 \mathrm{~cm} ; \mathrm{P}=0.029)$, and distant metastasis ( $\mathrm{P}=0.047)$.

Conclusion: Our results indicate that the methylation level of the SFRP1 promoter region is increased in patients with RCC compared to normal controls and might be involved in the occurrence and development of RCC. Additional well-designed studies are needed to further verify our conclusions.
\end{abstract}

(J Nippon Med Sch 2018; 85: 78-86)

Key words: SFRP1, promoter, methylation, renal cancer, meta-analysis

\section{Introduction}

Renal cell carcinoma (RCC) is a common lethal malignancy and accounts for more than $80 \%$ of kidney cancers. In the United States, there were approximately 62,700 new cases of kidney cancer and 14,240 deaths due to kidney cancer in $2016^{1}$. The incidence of RCC has increased at a rate of $1.6 \%$ per year in the last 10 years $^{2}$, and this increase is attributable to the increasing use and development of medical imaging technology. RCCs are usually resistant to chemotherapy and radiotherapy, and once they progress to distant metastasis, the 5-year survival is less than $5 \%{ }^{3}$. However, $20 \%-30 \%$ of patients with RCC with new diagnoses had still developed distant metastasis because RCC in the early stages usually has no clini- cal symptoms that differentiate this condition from healthy people ${ }^{4}$. Currently, surgical resection is still the main therapeutic treatment for RCC and has a good curative effect in cases of local RCC. It is necessary to identify effective biomarkers for the early surveillance and diagnosis of RCC.

The pathogenesis of RCC is complicated and has not yet been clarified. DNA methylation regulates gene expression without DNA sequence alteration and is a common form of epigenetic modification that plays an important role in the occurrence and development of tumors. The silencing of tumor suppressing factors is related to aberrant DNA hypermethylation in many tumors, including kidney tumors ${ }^{5}$. Some common clinical

Correspondence to Caiyong Lai, Department of Urology, The First Affiliated Hospital, Jinan University, No. 613 West Huangpu Avenue, Guangzhou 510630, Guangdong, China

E-mail: 294037978@qq.com

Journal Website (http://www2.nms.ac.jp/jnms/) 
samples, such as urine, blood, and ascites samples, also exhibit aberrant gene methylation alterations in human carcinomas. Thus, the detection technologies revolving around DNA methylation contribute to identifying noninvasive and convenient biomarkers to improve the diagnostic efficiency in cancer.

Wnt genes are a family of secreted glycoproteins that regulate cell proliferation ${ }^{6}$, differentiation ${ }^{7}$, and apoptosis $^{8}$. Wnts are involved in the pathogenesis of RCC because they activate other signaling pathways, including the $\beta$-catenin and mTOR pathways ${ }^{9}$. Secreted frizzledrelated protein 1 (SFRP1) belongs to the frizzle protein family and is a negative regulator of the Wnt signaling pathway that serves as a tumor-suppressor gene. The loss of SFRP1 is related to DNA hypermethylation in many tumors, including RCCs ${ }^{10,11}$. However, the results related to SFRP1 methylation in RCC are inconsistent. Thus, we performed a meta-analysis to assess the association between SFRP1 methylation and the RCC risk and its roles in the clinical characteristics of tumors.

\section{Literature Search Strategy}

The relevant literature was searched in PubMed, the Cochrane Library, Google Scholar, and the Wanfang Database (China) before August, 12, 2017. The key words were listed as follows: (renal OR kidney) AND (cancer OR carcinoma OR neoplasm) AND (methylation OR hypermethylation) AND (SFRP1 OR secreted frizzledrelated protein 1 ). The following conditions were the inclusion criteria for our meta-analysis: (1) the articles were published in English and/or Chinese. (2) The eligible articles must have had detailed information about the SFRP1 methylation level in RCC cases and normal controls and the clinical characteristics of the RCC patients. (3) The RCC cases were diagnosed definitively by pathology.

\section{Data Extraction}

Two reviewers (S.M. and Z.S.) reviewed the related articles and carefully extracted the useful data. The following data were recorded: the name of the first author, year of publication, country, sample source, tumor histology, detection method, case number, SFRP1 methylation level, normal control source, and clinical features (including gender, age, tumor size, tumor stage, histology grade, and distant metastasis). The specimens of the normal controls were derived from healthy people or RCCadjacent normal tissues. The articles that detected the methylation levels of the SFRP1 gene in both the tissue and serum groups were regarded as two separate articles. The tumor stage (T3-4) was regarded as high-stage or low-stage. The histological grade (G3-4) was classified as high-grade or low-grade.

\section{Quality Assessment}

To examine the quality of each included article, three reviewers (S.M., B.H., and W.C.) read the latest manual of the Newcastle-Ottawa Scale (NOS) carefully and assessed each study independently with uniform standards $^{12}$. Quality assessment was based on selection, comparability, and exposure. In NOS assessment, one star represented one point, and the range of the score in each group was from zero to nine. The articles that had six points or higher were included in our meta-analysis.

\section{Statistical Analysis}

The statistical results were examined in the form of pooled ORs and their corresponding 95\% CIs. The Cochrane's $Q$ test and Higgins $\mathrm{I}^{2}$ statistic were used to examine the methodological heterogeneity ${ }^{13}$. When the $\mathrm{P}$ value and $\mathrm{I}^{2}$ statistic indicated obvious heterogeneity in our meta-analysis $\left(\mathrm{P}<0.05\right.$ or $\left.\mathrm{I}^{2}>50 \%\right)$, a random-effects model (DerSimonian-Laird method) was chosen to calculate the pooled results. Otherwise, a fixed-effects model (the Mantel-Haenszel method) was selected. The potential heterogeneity was analyzed by meta-regression and subgroup analysis. Furthermore, sensitivity analysis was used to assess the stability of our results. Publication bias was assessed with funnel plots and Egger's tests. All statistical data were analyzed with STATA 12.0 software (Stata Corporation, TX, USA). $\mathrm{P}<0.05$ represented the level for statistical significance.

\section{Results}

\section{Study Filtration}

The flow diagram of the filtration process for obtaining eligible articles is presented in Figure 1. A total of 645 articles were preliminarily confirmed based on searches in four electronic databases. Via examination of the titles and abstracts, 248 repetitive articles were excluded. Then, after a detailed reading of the full texts of the remaining articles, 121 irrelevant articles were excluded. Sixty-five articles were removed because they focused on cell and/ or animal trials or lacked relevant methylation data. Finally, $10^{14-23}$ articles met our criteria and the average score of the NOS assessment for each included article was approximately 8 (Table S1). The characteristics of the included studies are presented in Table $\mathbf{1}$.

\section{Study Heterogeneity}

Obvious heterogeneity existed in our meta-analysis $\left(\mathrm{I}^{2}=\right.$ $65.5 \%$ ), so we used meta-regression and subgroup analysis to search for the sources of the methodological hetero- 
geneity. As demonstrated in Table 2, meta-regression could not identify any common source of heterogeneity (the $\mathrm{P}$ value for the method was 0.387 and the $\mathrm{P}$ value for the region was 0.577 ), but parts of the heterogeneity were derived from the detection method, control source, and region based on the subgroup analysis (Table 3).

The Association of SFRP1 Promoter Methylation with RCCs and Normal Controls

Eleven studies involving 535 RCC cases and 475 normal controls and were included in our meta-analysis. As presented in Figure 2, the results revealed that the fre-

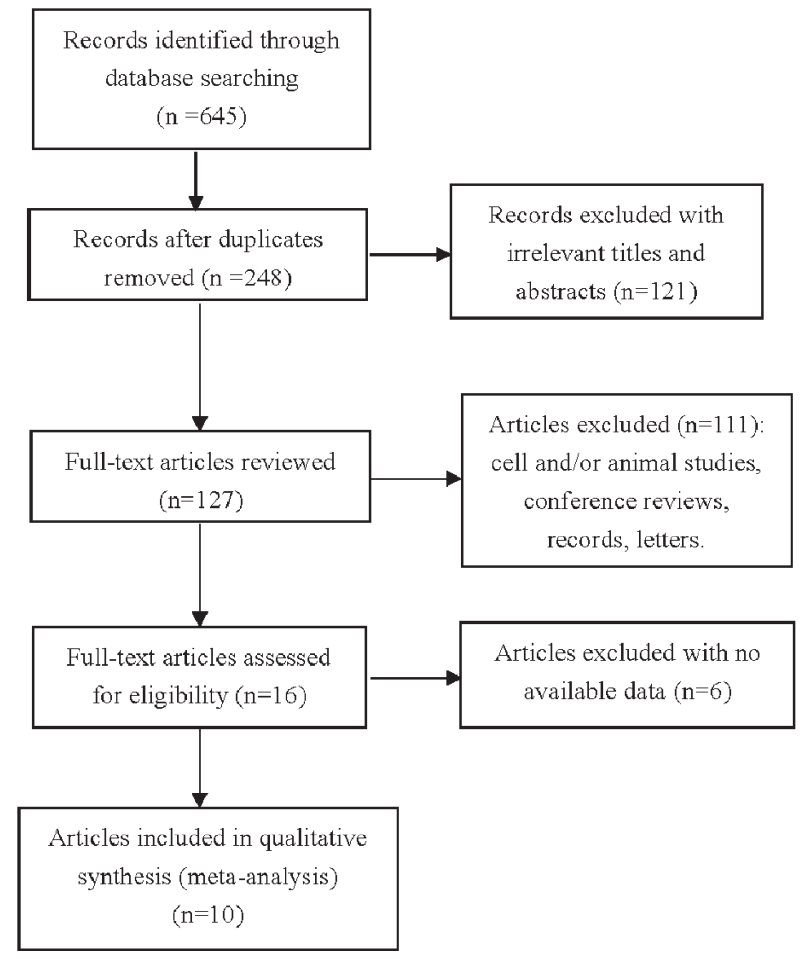

Fig. 1 Flow chart of literature search and selection. quency of SFRP1 promoter methylation was significantly higher in the RCC cases than in the normal controls (OR =13.72; 95\% CI: 6.01-31.28; P=0.000). Furthermore, the subgroup analysis indicated that the OR of the Caucasian subgroup $(\mathrm{OR}=13.74)$ was nearly equal to that of the Asian subgroup ( $\mathrm{OR}=14.50)$.

The Correlations of SFRP1 Promoter Methylation in RCC with the Clinical Features

The clinical information of the RCC cases is listed in Table 4 and includes tumor stage, histology grade, tumor size, distant metastasis, age, and gender. The results indicated that the methylation level of the SFRP1 promoter region in $\mathrm{RCC}$ was correlated with a higher stage $(\mathrm{OR}=$ 2.90, $\mathrm{P}=0.033)$, higher grade $(\mathrm{OR}=10.36, \mathrm{P}=0.000)$, the tumor size $(\mathrm{OR}=2.82, \mathrm{P}=0.029)$ and distant metastasis $(\mathrm{OR}=$ $3.67, \mathrm{P}=0.047)$. However, there were no associations with age $(\mathrm{P}=0.281)$ or gender $(\mathrm{P}=0.625)$.

\section{Sensitivity Analyses}

Sensitivity analysis was used to examine whether our results were stable. The pooled ORs presented in Figure 3 did not change, which indicated that the results of our meta-analysis were stable.

\section{Publication Bias}

As presented in Figure 4, the shape of the funnel plot was symmetrical, which meant that there was no obvious publication bias in our meta-analysis. This result was also confirmed by an Egger's test $(\mathrm{P}=0.063)$.

\section{Discussion}

RCC is a common lethal carcinoma that accounts for nearly $3 \%$ of all adult malignancies worldwide ${ }^{24}$. The pathogenesis of RCC is immensely complex. DNA methylation is one of the important pathogenetic mechanisms

Table S1 Results of the Newcastle-Ottawa Scale (NOS) assessment for case control studies

\begin{tabular}{|c|c|c|c|c|c|c|c|c|c|c|}
\hline \multirow{2}{*}{$\begin{array}{l}\text { First } \\
\text { author }\end{array}$} & \multirow{2}{*}{ Year } & \multicolumn{4}{|c|}{ Selection } & \multirow{2}{*}{$\frac{\text { Comparability }}{5}$} & \multicolumn{3}{|c|}{ Exposure } & \multirow{2}{*}{ Score } \\
\hline & & 1 & 2 & 3 & 4 & & 6 & 7 & 8 & \\
\hline Urakami & 2006 & $\star$ & $\star$ & $\star$ & $\star$ & $\star$ & $\star$ & $\star$ & $\star$ & 8 \\
\hline Dahl & 2007 & $\star$ & $\star$ & & $\star$ & $\star \star$ & $\star$ & $\star$ & $\star$ & 8 \\
\hline Michelle & 2007 & $\star$ & $\star$ & $\star$ & $\star$ & & $\star$ & $\star$ & $\star$ & 7 \\
\hline Awakura & 2008 & $\star$ & $\star$ & & $\star$ & $\star \star$ & $\star$ & $\star$ & $\star$ & 8 \\
\hline Dalgin & 2008 & $\star$ & $\star$ & & $\star$ & $\star \star$ & $\star$ & $\star$ & $\star$ & 8 \\
\hline Morris & 2010 & $\star$ & $\star$ & & $\star$ & $\star \star$ & $\star$ & $\star$ & $\star$ & 8 \\
\hline Costa & 2010 & $\star$ & $\star$ & $\star$ & $\star$ & & $\star$ & $\star$ & $\star$ & 7 \\
\hline Zhang & 2011 & $\star$ & $\star$ & & $\star$ & $\star \star$ & $\star$ & $\star$ & $\star$ & 8 \\
\hline Cheng & 2011 & $\star$ & $\star$ & $\star$ & $\star$ & $\star$ & $\star$ & $\star$ & $\star$ & 8 \\
\hline Atschekzei & 2012 & $\star$ & $\star$ & & $\star$ & $\star \star$ & $\star$ & $\star$ & $\star$ & 8 \\
\hline
\end{tabular}

1. Adequate definition of cases; 2. Representativeness of cases; 3 . Selection of controls; 4 . Definition of controls; 5. Control for important factors; 6 . Ascertainment of exposure; 7. Same method to ascertain for cases and controls; 8 . Non-response rate 
Table 1 Characteristics of the included studies

\begin{tabular}{|c|c|c|c|c|c|c|c|c|c|c|}
\hline \multirow{2}{*}{ Name } & \multirow{2}{*}{ Year } & \multirow{2}{*}{ Region } & \multirow{2}{*}{$\begin{array}{c}\text { Sample } \\
\text { type }\end{array}$} & \multirow{2}{*}{ Method } & \multirow{2}{*}{ Histology } & \multicolumn{2}{|c|}{ Tumor } & \multicolumn{2}{|c|}{ Control } & \multirow{2}{*}{$\begin{array}{l}\text { Control } \\
\text { source }\end{array}$} \\
\hline & & & & & & $\mathrm{M}+$ & Total & $\mathrm{M}+$ & Total & \\
\hline Urakami & 2006 & America & tissue & MSP & RCCs & 29 & 62 & 5 & 62 & $\mathrm{~A}$ \\
\hline Urakami & 2006 & America & serum & MSP & RCCs & 9 & 33 & 0 & 20 & $\mathrm{H}$ \\
\hline Dahl & 2007 & Germany & tissue & MSP & RCCs & 26 & 38 & 0 & 38 & $\mathrm{~A}$ \\
\hline Michelle & 2007 & America & tissue & MSP & ccRCC & 8 & 10 & 1 & 10 & A \\
\hline Awakura & 2008 & Japan & tissue & MSP & RCCs & 28 & 65 & 2 & 22 & A \\
\hline Dalgin & 2008 & America & tissue & MS & ccRCC & 34 & 38 & 4 & 38 & $\mathrm{~A}$ \\
\hline Morris & 2010 & England & tissue & MSP & RCCs & 20 & 58 & 0 & 20 & $\mathrm{~A}$ \\
\hline Costa & 2010 & Portugal & tissue & QMSP & RCCs & 5 & 31 & 1 & 5 & $\mathrm{H}$ \\
\hline Zhang & 2011 & China & tissue & MSP & ccRCC & 51 & 66 & 9 & 30 & A \\
\hline Cheng & 2011 & China & tissue & MSP & RCCs & 30 & 38 & 2 & 38 & $\mathrm{~A}$ \\
\hline Atschekzei & 2012 & Germany & tissue & Pyrosequencing & RCCs & 15 & 96 & 10 & 192 & $\mathrm{H}$ \\
\hline
\end{tabular}

Abbreviations: RCCs: renal cell carcinoma that is unclassified; ccRCC: clear cell renal cell carcinoma; M+: methylation; MSP: methylation-specific polymerase chain reaction; QMSP: quantitative methylation-specific polymerase chain reaction; MS: mass spectrometry; A: autologous (control specimens from the same patients); $\mathrm{H}$ : heterogeneous (control specimens from other individuals)

Table 2 Meta-regression of secreted frizzled-related protein 1 (SFRP1) promoter methylation in renal cancer

\begin{tabular}{lccccc}
\hline \multicolumn{1}{c}{ Variables } & Coefficient & $\begin{array}{c}95 \% \text { Confidence } \\
\text { interval }\end{array}$ & I $^{2}$-residual & Adjusted R & P value \\
\hline Method & -2.35 & $(-4.91,0.21)$ & $73.60 \%$ & $30.20 \%$ & 0.068 \\
Control type & -0.49 & $(-3.44,2.50)$ & $82.03 \%$ & $-15.11 \%$ & 0.729 \\
Ethnicity & -0.28 & $(-3.20,-2.66)$ & $82.26 \%$ & $-14.93 \%$ & 0.841 \\
\hline
\end{tabular}

I2-residual: residual variation due to heterogeneity; Adjusted R2: proportion of between-study variance

Table 3 Subgroup analyses of secreted frizzled-related protein 1 (SFRP1) promoter methylation in renal cell cancer (RCC) samples

\begin{tabular}{|c|c|c|c|c|c|c|c|c|c|c|}
\hline \multirow{2}{*}{ Variables } & \multirow{2}{*}{ Studies } & \multicolumn{2}{|c|}{ Tumor } & \multicolumn{2}{|c|}{ Control } & \multicolumn{3}{|c|}{ Pooled effect } & \multicolumn{2}{|c|}{ Heterogeneity } \\
\hline & & $M$ & $\mathrm{U}$ & $\mathrm{M}$ & $\mathrm{U}$ & OR $(95 \%)$ & $\mathrm{Z}$ & $\mathrm{P}$ & $\mathrm{I}^{2}(\%)$ & $P$ \\
\hline Total & 11 & 255 & 280 & 34 & 441 & $13.72(6.01-31.28)$ & 6.22 & 0.000 & $65.5 \%$ & 0.001 \\
\hline \multicolumn{11}{|l|}{ Method } \\
\hline MSP & 8 & 201 & 169 & 19 & 221 & $15.85(7.83-32.11)$ & 7.67 & 0.000 & $27.4 \%$ & 0.210 \\
\hline Non-MSP & 3 & 54 & 111 & 15 & 220 & $6.35(0.59-68.77)$ & 1.52 & 0.128 & $87.4 \%$ & 0.000 \\
\hline \multicolumn{11}{|l|}{ Control type } \\
\hline Autologous & 8 & 226 & 149 & 23 & 235 & $21.49(9.61-48.07)$ & 7.47 & 0.000 & $49.3 \%$ & 0.055 \\
\hline Heterogeneous & 3 & 29 & 131 & 11 & 206 & $3.15(1.00-9.92)$ & 1.96 & 0.050 & $24.1 \%$ & 0.268 \\
\hline \multicolumn{11}{|l|}{ Race } \\
\hline Caucasian & 8 & 146 & 220 & 21 & 364 & $13.74(4.37-43.21)$ & 4.48 & 0.000 & $70.0 \%$ & 0.002 \\
\hline Asian & 3 & 109 & 60 & 13 & 73 & $14.50(3.99-52.75)$ & 4.06 & 0.000 & $63.1 \%$ & 0.067 \\
\hline
\end{tabular}

M: methylation; U: non-methylation

in neoplasia and the progression of RCC. SFRP1 is regarded as a tumor suppressor gene, and the silencing of the SFRP1 gene is associated with aberrant DNA methylation in a number of human cancers, including breast ${ }^{25-30}$, colorectal $^{31-36}$, ovarian ${ }^{37}$, lung ${ }^{38,39}$, bladder ${ }^{40,41}$, hepatocellu$\operatorname{lar}^{42-45}$, gastric ${ }^{46}$, and renal cancers ${ }^{14,15,18}$, which means that SFRP1 promoter hypermethylation might be involved in the neoplasia of human tumors.

However, there were inconsistent results among the evaluated studies regarding the relationship between the methylation level of the SFRP1 gene and the incidence of RCC. In our meta-analysis, 11 case-control studies, consisting of 535 RCC cases and 475 normal controls, were included in the analysis. The results indicated that SFRP1 
Study

ID
Events, Events, \%

OR $(95 \% \mathrm{Cl})$
Tumor Control Weight

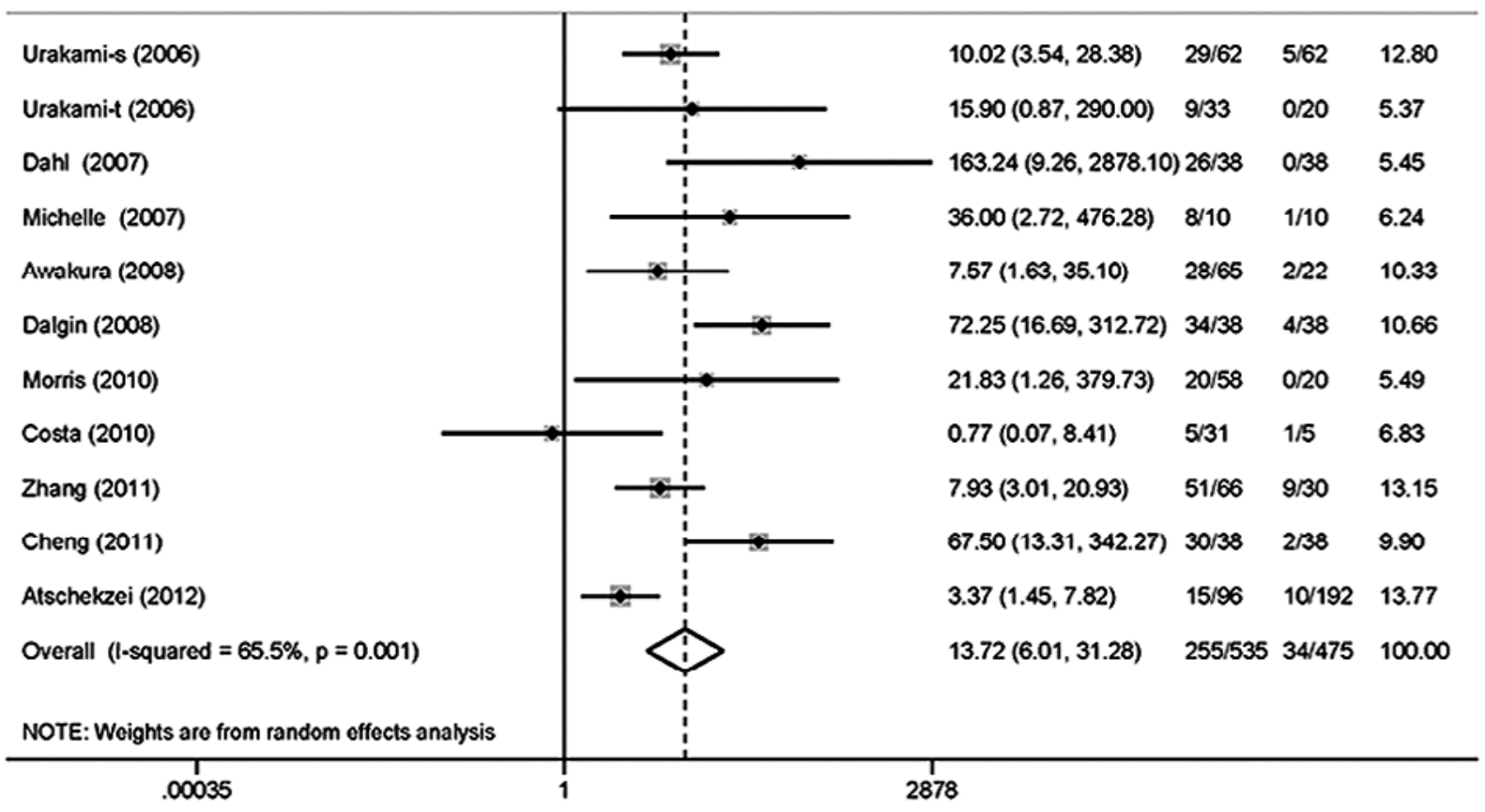

Fig. 2 Pooled OR from 11 studies including 535 RCC cases and 475 normal controls. OR=13.72; 95\% CI: 6.01-31.28; $\mathrm{P}=0.000$.

Table 4 The association of secreted frizzled-related protein 1 (SFRP1) promoter methylation with clinical features of patients with renal cancer

\begin{tabular}{|c|c|c|c|c|c|c|c|c|}
\hline \multirow{2}{*}{ Parameters } & \multirow{2}{*}{ No. } & \multirow{2}{*}{$\begin{array}{c}\text { Case/control } \\
\text { type }\end{array}$} & \multirow{2}{*}{$\begin{array}{l}\text { Cases } \\
\mathrm{M}+/ \mathrm{T}\end{array}$} & \multirow{2}{*}{$\begin{array}{c}\text { Controls } \\
\mathrm{M}+/ \mathrm{T}\end{array}$} & \multirow{2}{*}{ OR $(95 \%)$} & \multirow{2}{*}{$\mathrm{P}$} & \multicolumn{2}{|c|}{ Heterogeneity } \\
\hline & & & & & & & $\mathrm{I}^{2}(\%)$ & $\mathrm{P}$ \\
\hline Age & 4 & $\geqq 60 Y /<60 Y$ & $62 / 116$ & $34 / 70$ & $2.25(0.52-9.83)$ & 0.281 & 65.3 & 0.034 \\
\hline Gender & 4 & male/female & $71 / 131$ & $25 / 52$ & $1.25(0.51-3.03)$ & 0.625 & 22.0 & 0.278 \\
\hline Histology grade & 3 & G3-4/G1-2 & $19 / 25$ & $26 / 95$ & $10.36(3.46-31.00)$ & 0.000 & 0.0 & 0.532 \\
\hline Tumor stage & 5 & T3-4/T1-2 & $48 / 105$ & $63 / 177$ & $2.90(1.09-7.75)$ & 0.033 & 52.9 & 0.075 \\
\hline Size & 3 & $\geqq 5 \mathrm{~cm} /<5 \mathrm{~cm}$ & $37 / 82$ & $8 / 38$ & $2.82(1.11-7.14)$ & 0.029 & 0.0 & 0.460 \\
\hline Distant metastasis & 4 & Yes/No & $18 / 39$ & $42 / 177$ & $3.67(1.01-13.25)$ & 0.047 & 46.4 & 0.133 \\
\hline
\end{tabular}

$\mathrm{M}+$ : positive for SFRP1 methylation; T: total patients

promoter hypermethylation was highly correlated with an increased risk of RCC ( $\mathrm{OR}=13.72, \mathrm{P}=0.000)$. However, obvious heterogeneity existed in our meta-analysis $\left(\mathrm{I}^{2}=\right.$ $65.5 \%$ ). Through subgroup analysis, the method of methylation detection was able to explain part of the heterogeneity (the $\mathrm{I}^{2}$ for methylation-specific polymerase chain reaction (MSP) was $27.4 \%$; the $\mathrm{I}^{2}$ for non-MSP was $87.4 \%$ ) as different detection technology had its own standard to estimate the methylation. Quantitative detection methods including quantitative methylation-specific polymerase chain reaction (QMSP), mass spectrometry (MS) and pyrosequencing are usually more sensitive and specific than conventional $\mathrm{MSP}^{47}$. For example, Paola Parrella et al. ${ }^{48}$ observed that the methylation rate detected by MSP was $35.7 \%$ (10/28 cases) in normal brain tissue, however, only 2 out of 28 cases $(7.1 \%)$ were positive when detected by QMSP. Besides methodological heterogeneity, part of the heterogeneity was derived from different subtypes of RCC, lack of systemic treatment, and an exact definition of outcome as Sophie C Joosten et al. discussed ${ }^{49}$.

The results of the included studies detected only with the method of MSP had no obvious heterogeneity (27.4\%) and revealed that the frequency of SFRP1 methylation was also highly associated with the RCC risk $(\mathrm{OR}=15.85$, $\mathrm{P}=0.000$ ). Hypermethylation of the promoter $\mathrm{CpG}$ island of the SFRP1 gene has also been detected in RCC cell 


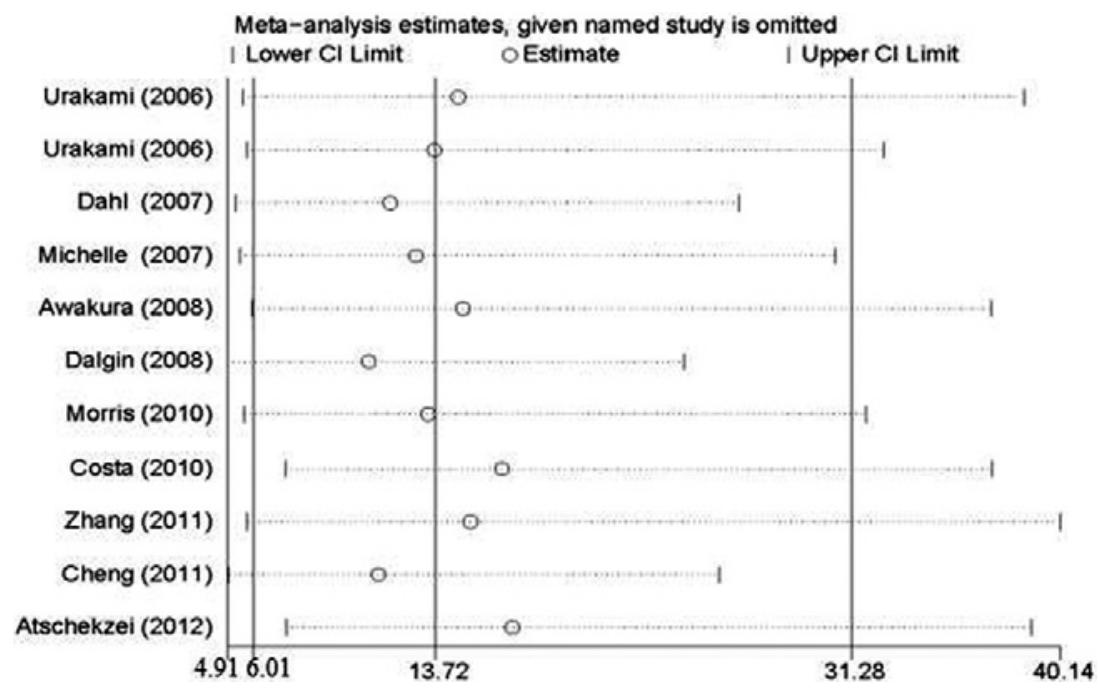

Fig. 3 Sensitivity analysis of the pooled ORs for SFRP1 promoter methylation.

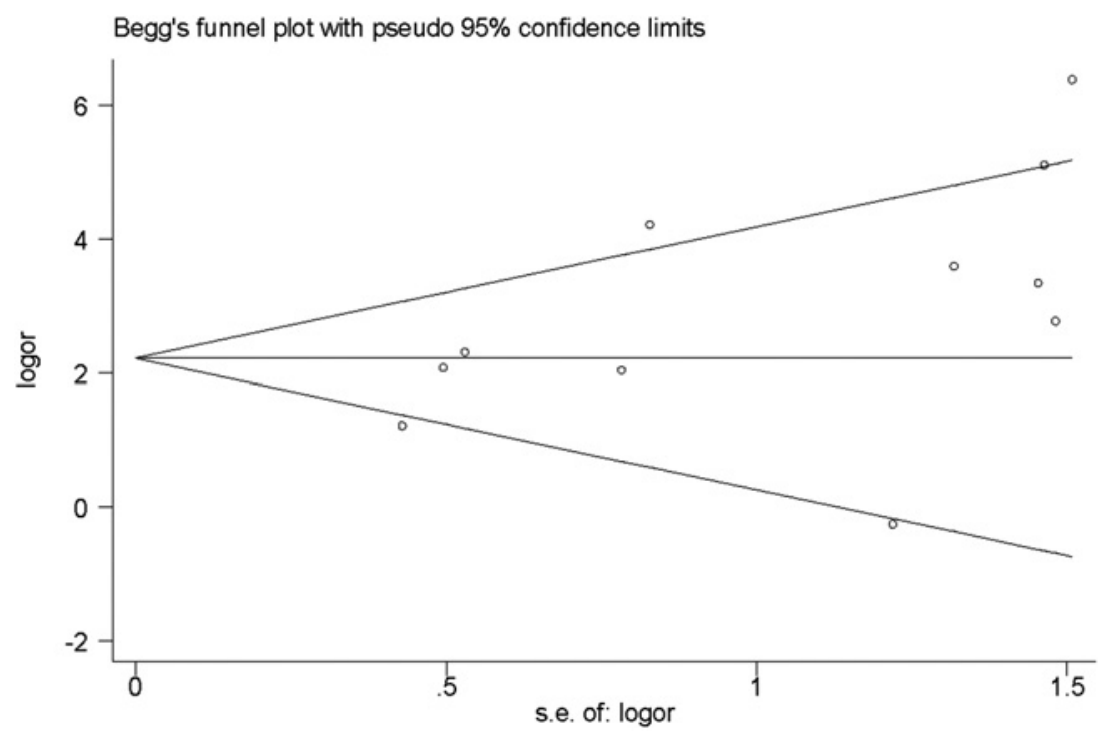

Fig. 4 Funnel plot of publication bias on the correlation between SFRP1 promoter methylation and renal cancer risk.

lines and is associated with decreased mRNA and protein expressions of the SFRP1 gene, and 5-aza-2'deoxycytidine treatment results in the restoration of SFRP1 expression and the inhibition of RCC cell growth $^{14,16,18}$, which indicates that SFRP1 promoter hypermethylation might be an early event in RCC tumorigenesis.

Several previous studies have reported that the methylation level of the SFRP1 promoter region is not associated with age or gender in several human cancers including cholangiocarcinomas ${ }^{50}$, acute myeloblastic leukemia $(\mathrm{AML})^{51}$, colorectal ${ }^{35}$, breast $^{29}$ and gastric cancers ${ }^{52}$. In our meta-analysis, 4 studies were included in the analysis of the results and indicated that there were no associations between SFRP1 promoter methylation and age (P
$=0.281)$ or sex $(\mathrm{P}=0.625)$ in the RCC samples.

Shinji Urakami et al. ${ }^{14}$ reported that the hypermethylation status of the SFRP1 gene was obvious in high-grade or metastatic RCCs. However, E Dahl et al. ${ }^{15}$ reported that there are no correlations between SFRP1 promoter methylation and the available clinicopathological data (i.e., tumor stage and histological grade and type) in RCC samples. The results of our meta-analysis revealed that the frequency of SFRP1 promoter methylation was associated with a higher histological grade $(\mathrm{P}=0.000)$, tumor stage $(P=0.033)$, tumor size $(\geqq 5 \mathrm{~cm} ; \mathrm{P}=0.029)$ and distant metastasis $(\mathrm{P}=0.047)$, which means that SFRP1 promoter methylation might be involved in the development of RCC.

A few potential limitations to our study are listed as 
follows. First, selection bias was inevitable because the articles were searched for only in the English and Chinese literature, and thus, we might have missed some important studies published in other languages. Second, the included articles were published several years ago (2006 to 2012), and newly published studies would have been better for inclusion in our analysis. Finally, the heterogeneity of our studies was clear $\left(\mathrm{I}^{2}=65.5 \%\right)$.

In conclusion, our study indicated that SFRP1 promoter hypermethylation is closely associated with a high risk of RCC. More well-designed research with sufficient sample sizes may clearly confirm the role of SFRP1 promoter methylation in RCC.

Acknowledgment: The research was supported by the Region Fund of the National Natural Science Foundation of China (No. 81460386).

Conflict of Interest: The authors declare that they have no conflict of interest.

\section{References}

1. Siegel RL, Miller KD, Jemal A: Cancer statistics, 2016. CA Cancer J Clin 2016; 66: 7-30.

2. SEER Stat Fact Sheets. Kidney and Renal Pelvis Cancer. Available from: http://seer.cancer.gov/statfacts/html/kid rp.html Accessed July 20, 2017.

3. Rasmussen F: Metastatic renal cell cancer. Cancer Imaging 2013; 13: 374.

4. Lam JS, Leppert JT, Belldegrun AS, Figlin RA: Novel approaches in the therapy of metastatic renal cell carcinoma. World journal of urology 2005; 23: 202-212.

5. Baylin SB: DNA methylation and gene silencing in cancer. Nature clinical practice Oncology 2005; 2: S4-S11.

6. Rulifson IC, Karnik SK, Heiser PW, Ten Berge D, Chen H, Gu X, Taketo MM, Nusse R, Hebrok M, Kim SK: Wnt signaling regulates pancreatic $\beta$ cell proliferation. Proceedings of the National Academy of Sciences 2007; 104: 62476252 .

7. Glass DA, Bialek P, Ahn JD, Starbuck M, Patel MS, Clevers $\mathrm{H}$, Taketo MM, Long F, McMahon AP, Lang RA: Canonical Wnt signaling in differentiated osteoblasts controls osteoclast differentiation. Developmental cell 2005; 8: 751-764.

8. Shiina $\mathrm{H}$, Igawa $\mathrm{M}$, Breault J, Ribeiro-Filho $\mathrm{L}$, Pookot $\mathrm{D}$, Urakami S, Terashima M, Deguchi M, Yamanaka M, Shirai M: The human T-cell factor-4 gene splicing isoforms, Wnt signal pathway, and apoptosis in renal cell carcinoma. Clinical cancer research 2003; 9: 2121-2132.

9. Banumathy G, Cairns P: Signaling pathways in renal cell carcinoma. Cancer biology \& therapy 2010; 10: 658-664.

10. Takada T, Yagi $Y$, Maekita T, Imura M, Nakagawa S, Tsao SW, Miyamoto K, Yoshino O, Yasugi T, Taketani Y: Methylation-associated silencing of the Wnt antagonist SFRP1 gene in human ovarian cancers. Cancer science 2004; 95: 741-744.

11. Awakura Y, Nakamura E, Ito N, Kamoto T, Ogawa O: Methylation-associated silencing of SFRP1 in renal cell carcinoma. Oncology reports 2008; 20: 1257-1263.

12. Stang A: Critical evaluation of the Newcastle-Ottawa scale for the assessment of the quality of nonrandomized studies in meta-analyses. European journal of epidemiology 2010; 25: 603-605.

13. Huedo-Medina TB, Sánchez-Meca J, Marín-Martínez F, Botella J: Assessing heterogeneity in meta-analysis: Q statistic or $\mathrm{I}^{2}$ index? Psychological methods 2006; 11: 193.

14. Urakami S, Shiina H, Enokida H, Hirata H, Kawamoto K, Kawakami T, Kikuno N, Tanaka Y, Majid S, Nakagawa M, Igawa M, Dahiya R: Wnt antagonist family genes as biomarkers for diagnosis, staging, and prognosis of renal cell carcinoma using tumor and serum DNA. Clinical cancer research: an official journal of the American Association for Cancer Research 2006; 12: 6989-6997.

15. Dahl E, Wiesmann F, Woenckhaus M, Stoehr R, Wild PJ, Veeck J, Knuchel R, Klopocki E, Sauter G, Simon R, Wieland WF, Walter B, Denzinger S, Hartmann A, Hammerschmied CG: Frequent loss of SFRP1 expression in multiple human solid tumours: association with aberrant promoter methylation in renal cell carcinoma. Oncogene 2007; 26: 5680-5691.

16. Gumz ML, Zou H, Kreinest PA, Childs AC, Belmonte LS, LeGrand SN, Wu KJ, Luxon BA, Sinha M, Parker AS, Sun LZ, Ahlquist DA, Wood CG, Copland JA: Secreted frizzled-related protein 1 loss contributes to tumor phenotype of clear cell renal cell carcinoma. Clinical cancer research: an official journal of the American Association for Cancer Research 2007; 13: 4740-4749.

17. Dalgin GS, Drever M, Williams T, King T, DeLisi C, Liou LS: Identification of novel epigenetic markers for clear cell renal cell carcinoma. The Journal of urology 2008; 180: 1126-1130.

18. Awakura $\mathrm{Y}$, Nakamura E, Ito N, Kamoto T, Ogawa O: Methylation-associated silencing of SFRP1 in renal cell carcinoma. Oncology reports 2008; 20: 1257-1263.

19. Costa VL, Henrique R, Ribeiro FR, Carvalho JR, Oliveira J, Lobo F, Teixeira MR, Jerónimo C: Epigenetic regulation of Wnt signaling pathway in urological cancer. Epigenetics 2010; 5: 343-351.

20. Morris MR, Ricketts C, Gentle D, Abdulrahman M, Clarke N, Brown M, Kishida T, Yao M, Latif F, Maher ER: Identification of candidate tumour suppressor genes frequently methylated in renal cell carcinoma. Oncogene 2010; 29: 2104-2117.

21. Zhang A, Yin F, Zhao Z, Ni X: Aberrant promoter methylation of SFRPs, the antagonists in renal clear cell carcinoma. Chinese Journal of Clinical Oncology 2011; 38: 1179-1182.

22. Atschekzei F, Hennenlotter J, Janisch S, Grosshennig A, Trankenschuh W, Waalkes S, Peters I, Dork T, Merseburger AS, Stenzl A, Kuczyk MA, Serth J: SFRP1 CpG island methylation locus is associated with renal cell cancer susceptibility and disease recurrence. Epigenetics 2012; 7: 447-457.

23. Jian-tang CHS: The relationship between MTHFR C677T gene polymorphism, methylation status and expression of SFRP 1 gene in renal clear cell carcinom. Journal of Modern Urology 2011; 16: 422-425.

24. Torre LA, Bray F, Siegel RL, Ferlay J, Lortet-Tieulent J, Jemal A: Global cancer statistics, 2012. CA Cancer J Clin 2015; 65: 87-108.

25. Armes JE, Hammet F, de Silva M, Ciciulla J, Ramus SJ, Soo WK, Mahoney A, Yarovaya N, Henderson MA, Gish K, Hutchins AM, Price GR, Venter DJ: Candidate tumorsuppressor genes on chromosome arm $8 p$ in early-onset 
and high-grade breast cancers. Oncogene 2004; 23: 56975702.

26. Klopocki E, Kristiansen G, Wild PJ, Klaman I, CastanosVelez E, Singer G, Stohr R, Simon R, Sauter G, Leibiger H, Essers L, Weber B, Hermann K, Rosenthal A, Hartmann A, Dahl E: Loss of SFRP1 is associated with breast cancer progression and poor prognosis in early stage tumors. International journal of oncology 2004; 25: 641-649.

27. Dahl E, Veeck J, An H, Wiesmann F, Klopocki E, Sauter G, Kristiansen G, Hartmann A, Knuchel R: [Epigenetic inactivation of the WNT antagonist SFRP1 in breast cancer]. Verhandlungen der Deutschen Gesellschaft fur Pathologie 2005; 89: 169-177.

28. Lo PK, Mehrotra J, D'Costa A, Fackler MJ, Garrett-Mayer E, Argani P, Sukumar S: Epigenetic suppression of secreted frizzled related protein 1 (SFRP1) expression in human breast cancer. Cancer biology \& therapy 2006; 5: 281-286.

29. Veeck J, Niederacher D, An H, Klopocki E, Wiesmann F, Betz B, Galm O, Camara O, Durst M, Kristiansen G, Huszka C, Knuchel R, Dahl E: Aberrant methylation of the Wnt antagonist SFRP1 in breast cancer is associated with unfavourable prognosis. Oncogene 2006; 25: 34793488.

30. Suzuki H, Toyota M, Carraway H, Gabrielson E, Ohmura T, Fujikane T, Nishikawa N, Sogabe $\mathrm{Y}$, Nojima M, Sonoda T, Mori M, Hirata K, Imai K, Shinomura Y, Baylin SB, Tokino T: Frequent epigenetic inactivation of Wnt antagonist genes in breast cancer. Br J Cancer 2008; 98: 11471156.

31. Caldwell GM, Jones C, Gensberg K, Jan S, Hardy RG, Byrd P, Chughtai S, Wallis Y, Matthews GM, Morton DG: The Wnt antagonist sFRP1 in colorectal tumorigenesis. Cancer research 2004; 64: 883-888.

32. Qi J, Zhu YQ, Luo J, Tao WH: Hypermethylation and expression regulation of secreted frizzled-related protein genes in colorectal tumor. World journal of gastroenterology 2006; 12: 7113-7117.

33. Qi J, Zhu YQ, Luo J, Tao WH: [The role of secreted Wntantagonist genes hypermethylation in early detection of colorectal tumor]. Zhonghua yi xue za zhi 2007; 87: 19541957.

34. Zhang W, Bauer M, Croner RS, Pelz JO, Lodygin D, Hermeking $\mathrm{H}$, Sturzl $\mathrm{M}$, Hohenberger $\mathrm{W}$, Matzel KE: DNA stool test for colorectal cancer: hypermethylation of the secreted frizzled-related protein-1 gene. Diseases of the colon and rectum 2007; 50: 1618-1626; discussion 26-27.

35. Rawson JB, Manno M, Mrkonjic M, Daftary D, Dicks E, Buchanan DD, Younghusband HB, Parfrey PS, Young JP, Pollett A, Green RC, Gallinger S, McLaughlin JR, Knight JA, Bapat B: Promoter methylation of Wnt antagonists DKK1 and SFRP1 is associated with opposing tumor subtypes in two large populations of colorectal cancer patients. Carcinogenesis 2011; 32: 741-747.

36. Salehi R, Mohammadi M, Emami MH, Salehi AR: Methylation pattern of SFRP1 promoter in stool sample is a potential marker for early detection of colorectal cancer. Advanced biomedical research 2012; 1: 87.

37. Takada T, Yagi $Y$, Maekita T, Imura M, Nakagawa S, Tsao SW, Miyamoto K, Yoshino O, Yasugi T, Taketani Y, Ushijima T: Methylation-associated silencing of the Wnt antagonist SFRP1 gene in human ovarian cancers. Cancer Sci 2004; 95: 741-744.

38. Fukui T, Kondo M, Ito G, Maeda O, Sato N, Yoshioka H, Yokoi K, Ueda Y, Shimokata K, Sekido Y: Transcriptional silencing of secreted frizzled related protein 1 (SFRP 1) by promoter hypermethylation in non-small-cell lung cancer. Oncogene 2005; 24: 6323-6327.

39. Zhang YW, Miao YF, Yi J, Geng J, Wang R, Chen LB: Transcriptional inactivation of secreted frizzled-related protein 1 by promoter hypermethylation as a potential biomarker for non-small cell lung cancer. Neoplasma 2010; 57: 228-233.

40. Neuhausen A, Florl AR, Grimm MO, Schulz WA: DNA methylation alterations in urothelial carcinoma. Cancer biology \& therapy 2006; 5: 993-1001.

41. Wang X, Wang H, Bu R, Fei X, Zhao C, Song Y: Methylation and aberrant expression of the Wnt antagonist secreted Frizzled-related protein 1 in bladder cancer. Oncology letters 2012; 4: 334-338.

42. Huang J, Zhang YL, Teng XM, Lin Y, Zheng DL, Yang PY, Han ZG: Down-regulation of SFRP1 as a putative tumor suppressor gene can contribute to human hepatocellular carcinoma. BMC cancer 2007; 7: 126.

43. Nomoto S, Kinoshita T, Kato K, Otani S, Kasuya H, Takeda S, Kanazumi N, Sugimoto H, Nakao A: Hypermethylation of multiple genes as clonal markers in multicentric hepatocellular carcinoma. Br J Cancer 2007; 97: 1260-1265.

44. Takagi H, Sasaki S, Suzuki H, Toyota M, Maruyama R, Nojima M, Yamamoto H, Omata M, Tokino T, Imai K, Shinomura Y: Frequent epigenetic inactivation of SFRP genes in hepatocellular carcinoma. Journal of gastroenterology 2008; 43: 378-389.

45. Kaur P, Mani S, Cros MP, Scoazec JY, Chemin I, Hainaut P, Herceg Z: Epigenetic silencing of sFRP1 activates the canonical Wnt pathway and contributes to increased cell growth and proliferation in hepatocellular carcinoma. Tumour biology: the journal of the International Society for Oncodevelopmental Biology and Medicine 2012; 33: 325336.

46. Nojima M, Suzuki H, Toyota M, Watanabe $Y$, Maruyama R, Sasaki S, Sasaki Y, Mita H, Nishikawa N, Yamaguchi K, Hirata K, Itoh F, Tokino T, Mori M, Imai K, Shinomura $\mathrm{Y}$ : Frequent epigenetic inactivation of SFRP genes and constitutive activation of Wnt signaling in gastric cancer. Oncogene 2007; 26: 4699-4713.

47. Cottrell SE: Molecular diagnostic applications of DNA methylation technology. Clinical biochemistry 2004; 37: 595-604.

48. Parrella P, la Torre A, Copetti M, Valori VM, Barbano R, Notarangelo A, Bisceglia M, Gallo AP, Balsamo T, Poeta ML, Carella M, Catapano D, Parisi S, Dallapiccola B, Maiello E, D'Angelo V, Fazio VM: High specificity of quantitative methylation-specific PCR analysis for MGMT promoter hypermethylation detection in gliomas. Journal of biomedicine \& biotechnology 2009; 2009: 531692.

49. Joosten SC, Deckers IA, Aarts MJ, Hoeben A, van Roermund JG, Smits KM, Melotte V, van Engeland M, TjanHeijnen VC: Prognostic DNA methylation markers for renal cell carcinoma: a systematic review. Epigenomics 2017; 9: 1243-1257.

50. Amornpisutt R, Proungvitaya S, Jearanaikoon P, Limpaiboon T: DNA methylation level of OPCML and SFRP1: a potential diagnostic biomarker of cholangiocarcinoma. Tumour biology: the journal of the International Society for Oncodevelopmental Biology and Medicine 2015; 36: 4973-4978.

51. Ghasemi A, Rostami S, Chahardouli B, Alizad Ghandforosh N, Ghotaslou A, Nadali F: Study of SFRP1 and SFRP2 methylation status in patients with de novo Acute Myeloblastic Leukemia. International journal of 
hematology-oncology and stem cell research 2015; 9: 1521.

52. Tahara $\mathrm{T}$, Maegawa $\mathrm{S}$, Chung $\mathrm{W}$, Garriga J, Jelinek J, Estecio MR, Shibata T, Hirata I, Arisawa T, Issa JP: Examination of whole blood DNA methylation as a potential risk marker for gastric cancer. Cancer prevention re- search (Philadelphia, Pa) 2013; 6: 1093-1100.

(Received, October 24, 2017)

(Accepted, January 15, 2018) 